\title{
Research on Organizational Citizenship Behavior, Trust and Customer Citizenship Behavior
}

\author{
Gongxing Guo ${ }^{1} \&$ Xing Zhou ${ }^{1}$ \\ ${ }^{1}$ School of Management, Xiamen University, Xiamen, China \\ Correspondence: Gongxing Guo, School of Management, Xiamen University, Xiamen, 361005, China. E-mail: \\ guogongxing@yahoo.cn
}

Received: March 21, 2013

Accepted: June 25, 2013

Online Published: July 16, 2013

doi:10.5539/ijbm.v8n16p86

URL: http://dx.doi.org/10.5539/ijbm.v8n16p86

\begin{abstract}
The concept of Customer Citizenship Behavior is evolved from Organizational Citizenship Behavior, and the relationship between them has been researched by few scholars. To examine the effect of Organizational Citizenship Behavior on Customer Citizenship Behavior, this research adopted questionnaire investigation method to survey 208 consumers. As predicted, the results showed that, organizational citizenship behavior influenced customer citizenship behavior positively; trust acted as a mediator between the relationships of organizational citizenship behavior and customer citizenship behavior. At last, the theoretical and practical significance, limitations of the study, as well as the direction of future research will be discussed.
\end{abstract}

Keywords: organizational citizenship behavior, trust, customer citizenship behavior, spillover effect

\section{Introduction}

The vigorous development of service industry makes the view of "customers as partial employees" gain more and more attention and recognition (Bowen \& Schneider, 1985). In addition to complete transactions with enterprises, customers are frequently participating in daily activities of enterprises, for example, participating in 360-degree performance appraisals, completing feedback questionnaires from enterprises or evaluating the service provided by enterprises. The increased importance of employees to the organization makes the effective management of customers considered to be one of the strategic advantages of enterprises (Lengnick-Hall, 1996). As this kind of extra-role behaviors of customers are progressively increasing, studies on Organizational Citizenship Behaviors (OCBs) which previously focused on employees has expanded to the customers, and appeared a new concept of Customer Citizenship Behaviors (CCBs).The literature review revealed that the study on citizenship behavior between organizations and customers are almost in a state of fragmentation; the study on OCB mainly concentrated within the organizations, while the study on CCB is mainly limited in the field of consumer behaviors.

According to the "commitment - trust theory" of relationship marketing, trust and commitment are the two key elements required by successful relationship marketing. Only when trust has been built and maintained between partners, can it lead to cooperative behavior so as to make the relationship marketing successful (Morgan \& Hunt, 1994). In the process of interacting with customers, OCBs taken by enterprises employees can establish trust relationships between enterprises and customers, which makes customers more willing to implement more "extra-role behaviors", i.e. more citizenship behavior will be taken by customers. Therefore, this research argues that OCB will develop trust between organizations and customers, and then lead to CCB (see figure 1).

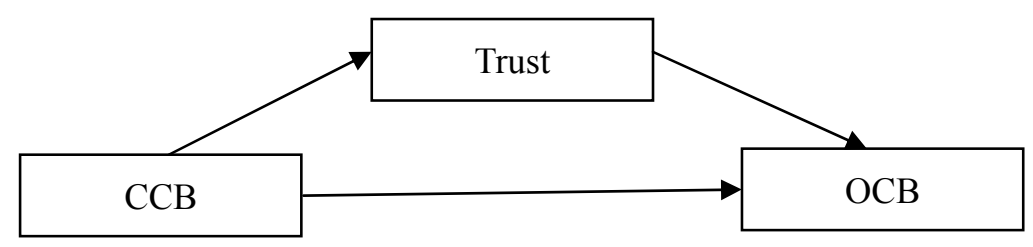

Figure 1. Research framework 


\section{Literature Review and Research Hypotheses}

\section{$2.1 O C B$ and $C C B$}

Since the emergence of the concept OCB, the researchers have conducted extensive research on the definition, dimensions, antecedent variables and outcome variables. Though OCB has been defined from different angles by various scholars, its basic connotation has been generally accepted including: (a) OCB is spontaneous behavior of employees, (b) OCB would not get direct or obvious return from the formal reward system of organization, (c) the long-term cumulative effects of OCB can help to enhance the overall performance of the organization (Podsakoff et al., 2000). In recent years, the researchers have been carrying on discussion and research from some new angles, such as cross-cultural studies of OCB (Farh \& Zhong, 2004). The concept and dimensions of citizenship behavior has been extended to the customer from the organization. Gruen (1995) define buyers' CBs as customer exercise important but voluntary behaviors that are valued but not related directly to enforceable requirements by the organization. Groth (2005) also defined CCBs as voluntary and discretionary behaviors that are not required for the successful production and/or delivery of the service but that, in the aggregate, help the service organization overall. After this, Yi \& Gong (2006) and Bove et al. (2008) also defined the concept of CCB, but have no significant difference in essence from Groth's.

Throughout these studies, we found that not only the relatively mature research on OCB had not yet appeared achievements across the organization and customers, but also CCB as a concept evolution from OCB, had not occurred studies on the relationship between them. As far back as 2005, Groth had pointed out that just as employee satisfaction has been shown to "spill over" to customer satisfaction, employees "pay a little more" often get a return from customers. When customers interact with organization, their exchange can similarly be considered as a social exchange (Bowen, 1990). According to social exchange theory, when people get benefits from others, they tend to think that they have an obligation to return on this kind of benefit. If customers think organization fully fulfilled his promise when they in exchange with the organization, that is to say organization provide customers with satisfactory goods and services, customers are more likely to take appropriate actions to reciprocate organization. For example, when we felt satisfied instead of qualified service in the bank for business, we were more likely to respond to a "satisfaction" service evaluation. Thus, it is hypothesized that:

Hypothesis 1: OCB will have a positive effect on CCB.

\subsection{The Mediating Effect of Trust}

Although the definitions of OCB are different, scholars reach a consensus on the connotation. They regard OCB as an altruistic and courtesy behavior with sense of responsibility. These behaviors can contribute to make a deal when organization contraction with customers, and to allow customers to create a feeling of receiving service more than expected. According to social exchange theory, unlike the economic exchange is short-term, paid exchange, social exchange is a kind of swap based on trust, longer-term, and this long-term exchange is often not specific and beyond expectations (Blau, 1964). The establishment of trust is a dynamic process (Schweitzer et al., 2006), so trust can gradually build up by the information exchange increasing between the two sides. Along with the increase in exchange, the customer and the organization will become familiar, and the trust relationship and return behavior of both sides will promote.

Although it is assumed that social exchange is based on individuals in previous studies, lots of studies on relationship marketing demonstrate that customers always establish relations with organization. Customers tend to create a sense of responsibility on organization but not on individuals when they feel trust and expectation from organization. When customers feel satisfied with or get additional treatment more than expected from the organization services, they will trust the organization and more likely to take voluntary behaviors - also CCB to reciprocate organization. Thus, it is hypothesized that:

Hypothesis 2: trust acts as a mediator between the relationships of OCB with CCB.

\section{Research Method}

\subsection{Research Object}

To test the model, the data of this research were collected through a questionnaire survey of Chinese consumer. The respondents for the questionnaire survey were college students because they shopping online actively. Of the 250 consumers that we visited, 223 consumers finally responded to the survey request. Among them, 208 questionnaires were valid, and the effective response rate for the survey is $83 \%$. The majority respondents are women, accounting for 54.3 percent of the sample. In term of age, the majority respondents are between the ages of 21-30, accounting for 93.8 percent of the sample. $93.7 \%$ of respondents are undergraduates and over. 


\subsection{Measures Tool}

In order to ensure the validity and reliability of measuring tools, this research used scales which have been used in previous research, and modified them properly according to the specific research needs. Before the formal investigation, some consumers were selected to conduct pre-survey to assess the appropriateness of questionnaire design, then the questionnaire was modified according participants' advices.

(a) $O C B$ was assessed with a modified measure developed by Podsakoff et al. (1997). The scale consists of 9 items that were assessed on 7-point scale, ranging from 1(strongly disagree) to 7(strongly agree). In order to guarantee the consistency of the data source, consumers' perception of OCB had been used as measure standard. This measure showed an internal consistency estimate of $\alpha=0.84$.

(b) Trust was assessed with a measure developed by Morgan \& Hunt (1994). The scale consists of 3 items that were assessed on 7-point scales, ranging from 1(strongly disagree) to 7(strongly agree). This measure showed an internal consistency estimate of $\alpha=0.91$.

(c) $C C B$ was assessed with a modified measure developed by Groth (2005). The scale consists of 9 items that were assessed on 7-point scales, ranging from 1(strongly disagree) to 7 (strongly agree). This measure showed an internal consistency estimate of $\alpha=0.89$.

(d) Three control variables were used in the survey: gender, age and educational status.

\subsection{Data Analysis and Results}

Means, standard deviations, and correlation coefficients of all variables are shown in Table 1. As shown, OCB and trust were intercorrelated (coefficients of $.54, \mathrm{p}<.01$ ); OCB and CCB were intercorrelated (coefficients of .51, $\mathrm{p}<.01$ ); also trust and CCB were intercorrelated (coefficients of .66, $\mathrm{p}<.01$ ). To further assess validity of all measures, a measurement model was subjected to factor analysis, the result shows that the indicators' factor loadings are all greater than .5, and the AVE square-root is greater than the correlation coefficient between variables, it means that there are good convergent and discriminant validity of all measures.

Table 1. Means, standard deviations, and correlation coefficients of all Measures

\begin{tabular}{lcccccc}
\hline variables & 1 & 2 & 3 & 4 & 5 & 6 \\
\hline 1.gender & & & & & & \\
2.age & 0.01 & & & & & \\
3.edu & 0.01 & 0.06 & & & & \\
4.OCB & $0.20^{* *}$ & -0.01 & 0.05 & & & \\
5.trust & 0.05 & -0.13 & 0.01 & $0.54^{* *}$ & & \\
6.CCB & $0.20^{* *}$ & -0.05 & 0.06 & $0.51^{* *}$ & $0.66^{* *}$ & \\
\hline Mean & 1.54 & 2.03 & 3.45 & 4.67 & 4.81 & 4.80 \\
S.D. & 0.50 & 0.25 & 0.64 & 0.97 & 1.19 & 1.13 \\
\hline
\end{tabular}

Note: $\mathrm{N}=208 ; * \mathrm{p}<.05$ (two-tailed), ${ }^{* *} \mathrm{p}<.01$ (two-tailed).

To test Hypotheses 1 and 2, hierarchical regression analyses were conducted (see Table 2). 
Tables 2. Results of hypotheses testing

\begin{tabular}{|c|c|c|c|c|c|c|}
\hline & \multicolumn{2}{|c|}{ Trust } & \multicolumn{4}{|c|}{$\mathrm{CCB}$} \\
\hline & M1 & M2 & M3 & M4 & M5 & M6 \\
\hline \multicolumn{7}{|l|}{ C.V. } \\
\hline gender & 0.05 & -0.06 & $0.20 * *$ & 0.11 & $0.17 * *$ & $0.14 * *$ \\
\hline age & -0.13 & $-0.12 *$ & -0.06 & -0.05 & 0.03 & 0.02 \\
\hline edu & 0.02 & -0.01 & 0.06 & 0.04 & 0.05 & 0.04 \\
\hline \multicolumn{7}{|l|}{ I.V. } \\
\hline OCB & & $0.55^{* *}$ & & $0.49 * *$ & & $0.18^{* *}$ \\
\hline \multicolumn{7}{|l|}{ MED. } \\
\hline trust & & & & & $0.66^{* *}$ & $0.57 * *$ \\
\hline $\mathbf{R}^{2}$ & 0.20 & 0.31 & 0.05 & 0.27 & 0.47 & 0.49 \\
\hline$\Delta \mathbf{R}^{2}$ & 0.20 & 0.29 & 0.05 & 0.23 & 0.43 & 0.22 \\
\hline $\mathbf{F}$ & 1.40 & $23.00 * *$ & 3.42 & $19.20 * *$ & $45.59 * *$ & $39.41 * *$ \\
\hline$\Delta \mathbf{F}$ & 1.40 & $86.01 * *$ & 3.42 & $63.40 * *$ & $163.93 * *$ & $87.54 * *$ \\
\hline
\end{tabular}

Notes: $\mathrm{N}=208 ;{ }^{*} \mathrm{p}<.05,{ }^{* * \mathrm{p}}<.01$.

Main effect. Hypothesis 1 predicted that OCB would have a positive effect on CCB. To test this hypothesis, a hierarchical regression analysis was conducted in which the three control variables were entered in the first step, OCB was entered in the second step. As shown in Table 2, OCB (M4, $\beta=.49, \mathrm{p}<.01)$ was positively related to CCB. Hence, Hypothesis 1 was supported.

The mediating effect of trust. Hypothesis 2 predicted that trust acted as a mediator between the relationships of OCB with CCB. According to the suggestion by Baron and Kenny (1986), four steps were conducted to test the mediating effect of trust. Firstly, the impact of independent variable on dependent variable is significant, this had been supported in Hypothesis 1; secondly, the impact of independent variable on mediator is significant; thirdly, the impact of mediator on dependent variable is significant; finally, checkout the mediating effect. As shown in Table 2, OCB (M2, $\beta=.55, \mathrm{p}<.01)$ was positively related to trust, and trust (M5, $\beta=.66, \mathrm{p}<.01)$ was positively related to CCB. Controlling for the mediator (trust), the effect of the OCB on the CCB deceased ( $\beta$ reduced from 0.49 to 0.18 ), but still different from 0 ( $\beta$ was still significant), and trust was also positively related to $\mathrm{CCB}(\mathrm{M} 6, \beta=.57, \mathrm{p}<.01)$, Hence, trust acted as a partial mediator between the relationships of OCB with $\mathrm{CCB}$, Hypothesis 2 was partially supported. Further, a Sobel test was conducted to test the significance of mediating effect based on Sobel's proposal (Sobel, 1982). Result substantiated that the mediating effect of trust was significant in the relationship between OCB and CCB $(\mathrm{Z}=6.58, \mathrm{p}<.01)$. Hence, Hypothesis 2 received further support.

\section{Discussion}

\subsection{Conclusions}

In this research, we used a questionnaire survey to examine the impact of OCB on CCB. The conclusions of this research as follows: (a) organizational citizenship behavior have a positive effect on customer citizenship behavior; (b) trust acted as a partial mediator between the relationships of organizational citizenship behavior and customer citizenship behavior.

\subsection{Theoretical and Practical Implications}

This research makes two important theoretical contributions: (a) the research responds to Groth and other scholars' appeal to study on the reward behaviors between organization employees and customers, providing a direction for future research on citizenship behavior; (b) the research effectively describes the mechanism of action of OCB on CCB by introducing trust as mediator.

In addition to its theoretical contributions, this research also has important practical implications. It provides a train of thought to strengthen customer management for enterprises. Enterprises can strengthen the internal employees' management to spur them to implement more citizenship behaviors, to gain the trust of customers, and make customer implement more return behaviors, ultimately achieve the goal of manage customers effectively.

\subsection{Limitations and Directions for Future Research}

This research also has a number of limitations that deserve mention. Measuring tools of this research were all 
developed in western cultural backgrounds and organization situations. It is therefore doubted whether they fit Chinese actual condition or not. In this study, the consumers were required to recall the latest shopping experience no matter them shopping online or offline. In light of this, we encourage future studies to distinguish customers' online and offline shopping experience, to improve external validity of the research conclusion.

\section{Acknowledgements}

This article was supported by the Humanities and Social Science Research Project of Chinese Ministry of Education (11YJA630215) and the 2012 Educational Office Research Program of Fujian Province, China.

\section{References}

Baron, R. M., \& Kenny, D. A. (1986). The moderator-mediator variable distinction in social psychological research: conceptual, strategic, and statistical considerations. Journal of Personality and Social Psychology, 51(6), 1173-1182. http://dx.doi.org/10.1037/0022-3514.51.6.1173

Blau, P. M. (1964). Exchange and Power in Social Life. New York: John Wiley.

Bove, L. L., Pervan, S. J., Beatty, S. E., \& Shiu, E. (2009). Service worker role in encouraging customer organizational citizenship behaviors. Journal of Business Research, 62(7), 698-705. http://dx.doi.org/10.1016/j.jbusres.2008.07.003

Bowen, D. E. (1990). Interdisciplinary study of service: some progress, some prospects. Journal of Business Research, 20(1), 71-79. http://dx.doi.org/10.1016/0148-2963(90)90044-E

Bowen, D. E., \& Schneider, B. (1985). Boundary spanning role employees and the service encounter: some guidelines for management and research. In J. A. Czepiel, M. R. Solomon, \& C. Surprenant (Eds.), The service encounter (pp. 127-147). Lexington, MA: D. C. Heath.

Farh, J. L., \& Zhong, C. B. (2004). Organizational citizenship behavior in the People's Republic of China. Organization Science, 15(2), 241-253. http://dx.doi.org/10.1287/orsc.1030.005

Groth, M. (2005). Customers as good soldiers: examining citizenship behaviors in internet service deliveries. Journal of Management, 31(1), 7-27. http://dx.doi.org/10.1177/0149206304271375

Gruen, T. W. (1995). The outcome set of relationship marketing in consumer markets. International Business Review, 4(4), 447-469. http://dx.doi.org/10.1016/0969-5931(95)00026-7

Lengnick-Hall, C. A. (1996). Customer contributions to quality: A different view of the customer-oriented Firm. Academy of Management Review, 21(3), 791-824. Retrieved from http://www.jstor.org/stable/259002

Morgan, R. M., \& Hunt, S. D. (1994). The commitment-trust theory of relationship marketing. Journal of Marketing, 58(3), 20-38. http://dx.doi.org/10.2307/1252308

Podsakoff, P. M., \& MacKenzie, S. B. (1997). Impact of organizational citizenship behavior on organizational performance: A review and suggestion for future research. Human Performance, 10(2), 133-151. http://dx.doi.org/10.1207/s15327043hup1002_5

Podsakoff, P. M., MacKenzie, S. B., Paine, J. B., \& Bachrach, D. G. (2000). Organizational citizenship behaviors: A critical review of the theoretical and empirical literature and suggestions for future research. Journal of Management, 26(3), 513-563. http://dx.doi.org/10.1177/014920630002600307

Schweitzer, M. E., Hershey, J. C., \& Bradlow, E. T. (2006). Promises and lies: Restoring violated trust. Organizational Behavior and Human Decision Processes, 101(1), 1-19. http://dx.doi.org/10.1016/j.obhdp.2006.05.005

Sobel, M. E. (1982). Asymptotic confidence intervals for indirect effects in structural equation models. In Leinhardt, S. (Ed.), Sociological methodology, 13, 290-312. Washington, D. C.: American Sociological Association. http://dx.doi.org/10.2307/270723

Yi, Y., \& Gong, T. (2006). The antecedents and consequences of service customer citizenship and badness behavior. Seoul Journal of Business, 12(2), 145-176. REtrived from http://strathprints.strath.ac.uk/38577/

\section{Copyrights}

Copyright for this article is retained by the author(s), with first publication rights granted to the journal.

This is an open-access article distributed under the terms and conditions of the Creative Commons Attribution license (http://creativecommons.org/licenses/by/3.0/). 